\title{
A SUBVERSÃO FEMININA NA REESCRITA DO MITO DE PENÉLOPE EM A ODISSEIA DE PENÉLOPE, DE MARGARET ATWOOD
}

Elis Regina Fernandes Alves ${ }^{1}$ Sara Almieira da Rocha ${ }^{2}$

RESUMO: Analisa-se o romance A odisseia de Penélope (2005), de Margaret Atwood à luz da crítica feminista. Objetiva-se analisar a reescrita da Odisseia, de Homero, que dá voz à Penélope, tornando-a protagonista. O feminismo elucida a evolução da escrita feminina, a figuração de personagens femininas, que, de estereotipadas, passaram a se mostrar mais independentes, ousadas e insubmissas, conforme avançavam as conquistas femininas na sociedade. De caráter bibliográfico, este trabalho utiliza referencial teórico sobre os feminismos como movimentos sociais, o feminismo na literatura, com base em Alves e Pitanguy (1985), Beauvoir (1980 a e b), Woolf (2019), Michel (1982), Showalter (2014), Bordieu (2019), dentre outros. A análise revela que esta nova Penélope, que analisa e reconta sua história três mil anos após sua morte, é questionadora e insubordinada. Entende seu papel de submissão no passado, descortina o falso heroísmo de Odisseu e dá voz às escravas enforcadas na Odisseia, caso minimizado por Homero, denunciando sua injustiça, revelando que na visão masculina, eram sujas e mentirosas, mas, para Penélope, eram companheiras que a ajudaram. Esta Penélope simboliza a evolução feminina, tanto em papeis sociais quanto na figuração literária, pois de submissa, frágil e calada, torna-se insurreta, consciente de si, digna de protagonismo.

Palavras-chave: Reescrita; Crítica literária feminista; A odisseia de Penélope.

\section{FEMALE SUBVERSION IN THE PENELOPE MYTH'S REWRITING IN MARGARET ATWOOD'S THE PENELOPIAD}

ABSTRACT: An analysis of The Penelopiad (2005), by Margaret Atwood is provided by feminist criticism. The aim is to analyze the rewriting of The Odyssey, by Homer, that gives speech to Penelope, making her a protagonist. The feminist criticism illuminates the evolution of feminine authorship, as well as the representation of female characters who, from stereotyped ones, became more independent, bold and unruly, as the female conquests rose in social areas. This work is bibliographical and uses theories about feminisms as social movements, as well as the feminist theory in literature, in authors such as Alves and Pitanguy (1985), Beauvoir (1980 a and b), Woolf (2019), Michel (1982), Showalter (2014), Bordieu (2019), and others. The analysis reveals that this new Penelope, who analyses and retells her own story three

\footnotetext{
${ }^{1}$ Professora Adjunta da Universidade Federal do Amazonas- IEAA- Instituto de Educação, Agricultura e Ambiente de Humaitá-AM. E-mail: elisregi@ufam.edu.br

${ }^{2}$ Graduanda do curso de Letras- Português e Inglês da Universidade Federal do Amazonas- IEAAInstituto de Educação, Agricultura e Ambiente de Humaitá-AM. Bolsista de PIBIC. E-mail: saraalmieira2@gmail.com
} 
thousand years after her death, is questioning and rebellious. She understands her own submissive rule in the past, she unveils Odisseus' false heroism of, and gives voice to the hanged women slaves, what was minimized in The Odyssey. She denounces this injustice, revealing that in men's view the slaves were dirty and liars, but for Penelope they were friends who helped her. This Penelope symbolizes the female evolution both in social rules and in literary representation, because from submissive, fragile and silent, she became insurgent, self-conscious and worthy of protagonism.

Keywords. Rewriting, Feminist criticism, The Penelopiad.

\section{INTRODUÇÃO}

Análises literárias com enfoque feminista têm sua relevância no cenário literário atual na medida em que ajudam a desvelar a posição subalterna relegada às personagens femininas ao longo de séculos nas literaturas canonizadas. Assim, analisar obras em que essa posição é solapada é uma forma de evidenciar como a literatura produzida sobre mulheres e por mulheres tem ajudado a desconstruir estereótipos machistas e reducionistas, figurando mulheres insubmissas, que dão voz, de forma metafórica, a um grupo de mulheres, como se nota no romance $A$ odisseia de Penélope, publicado em 2005, de Margaret Atwood, em que a própria Penélope e as escravas assassinadas se tornam um símbolo das mulheres que questionam sua suposta subalternidade.

Esta pesquisa analisa como a reescrita de Margaret Atwood faz uma subversão do papel de submissão dado à Penélope na Odisseia, desconstruindo os estereótipos acerca da mulher, dando-lhe voz e fazendo-a questionadora, irônica e insubordinada. Para tanto, discute-se, inicialmente, quais eram os papéis dessas mulheres na sociedade patriarcal da Grécia Antiga, a evolução da mulher ao longo dos séculos, o feminismo como crítica literária, explicando como ocorrem as fases literárias feministas, e uma comparação da personagem Penélope dessa obra com a da Odisseia de Homero. Verifica-se como se dá essa subversão, investigando como a autora desconstrói a imagem de Penélope como mulher passiva, ouvindo a sua versão da história. Importa, ainda, discutir a evolução do movimento literário feminista, investigando como a escrita sobre mulheres e feita por mulheres foi se modificando 
conforme mudava a posição das mulheres na sociedade, bem como discutir os estereótipos mais comuns imputados às mulheres pelas literaturas canônicas.

Para tanto, inicialmente, esta pesquisa irá consistir na leitura e discussão da teoria literária feminista, analisando sua sistematização, verificando como ao longo do tempo a literatura produzida sobre mulheres e por mulheres foi se modificando de forma a renegar os estereótipos comumente atribuídos às mulheres, subvertendo papeis, questionando e criticando. Para atingir este intento, utilizaremos autores como Bourdieu (2019), Michel (1982), Alves e Pitanguy (1985), Zolin (2003a e b); Bonnici (2007), Woolf (2019), Beauvoir (1980 a e b), Saffiot (1976), dentre outros. Considerando, ainda, a fortuna crítica sobre Margaret Atwood no Brasil, verifica-se que trabalhos importantes foram feitos sobre suas obras. Sobre este romance, destaca-se a dissertação de mestrado de Maria do Rosário Silva Leite intitulada The Penelopiad: A reconstrução do mito por Margaret Atwood, pela UFPA, em 2010, que destaca justamente a subversão feita por Atwood ao dar voz à personagens femininas, com foco no mito, além de autores como Lima (2013), Renaux (2009), Ribeiro e Silva (2014), que servirão de base para compreendermos como Atwood tem sido discutida em trabalhos recentes no Brasil, e dar vazão a outra análise que versa, mais especificamente, sobre a crítica feminista. Após o entendimento da crítica feminista, a obra de Atwood será analisada e comparada com a de Homero, de modo que trechos sejam utilizados para comparar a caracterização das duas Penélopes.

\section{O PAPEL DA MULHER AO LONGO DOS SÉCULOS}

A mulher quase sempre foi subordinada ao homem e definida por seu sexo, sendo estereotipada como "fraca, passiva e instintiva" (BONNICl, 2007, p.79). Entretanto, com o passar dos séculos, ela começou a questionar sua própria existência e o motivo de sua inferioridade, não aceitando mais a imposição de casamentos escolhidos, passando por fases em que reivindicavam direitos de igualdade, de serem reconhecidas como indivíduos capazes, de terem poder de escolha e autonomia. Enquanto isso, o homem sempre pôde desempenhar várias funções e criar leis ao seu favor, porque era assim que funcionava a sociedade patriarcal. 
As mulheres, muitas vezes, desconheciam as opressões e os controles que a sociedade machista exercia sobre elas, pois eram interpeladas por discursos mais fortes que estavam perpetuados na sociedade por muito tempo, sendo, novamente, relegadas à submissão, como entende Bordieu (2019), ao analisar a dominação masculina e a violência simbólica que se impunha por meio destes discursos de inferiorização. Os homens as dominavam, determinavam suas tarefas. As mulheres brancas, ocidentais, de classe média e alta tinham a função de reprodução, cuidar da casa e do marido, não tendo o direito de opinar, de pensar, de receber educação formal e profissionalizante, de votar, cabendo todos estes privilégios aos homens. Por não perceberem a opressão, acabavam, por vezes, concordando com a posição à qual eram relegadas. Kate Millett (1970), uma das precursoras da crítica feminista, discutiu como o consentimento à opressão feminina era obtido através de instituições como a família, a escola, a igreja, e as leis sociais que permitem a violência contra a mulher, por exemplo.

Beauvoir (1980a) entendeu que isso se dá porque na infância as meninas eram ensinadas a não questionar, apenas a aceitar o lugar a que pertenciam e se agissem diferentes ou igual a um menino, logo eram punidas. Segundo Perrot (2007, p. 91), os gregos acreditavam que era indecente e vergonhoso uma mulher falar em público, já que ela estaria abaixo do homem, colocando a religião como explicação para esse fato: “Como é sagrado, o saber é o apanágio de Deus e do Homem, seu representante sobre a terra. É por isso que Eva cometeu o pecado supremo. Ela, mulher, queria saber; sucumbiu à tentação do diabo e foi punida por isso." Sobre o papel de obediência que precisava cumprir, Zolin (2003a, p.164) analisa que "a mulher que tentasse usar seu intelecto, ao invés de explorar sua delicadeza, compreensão, afeição ao lar, inocência e ausência de ambição, estaria violando a ordem natural das coisas, bem como a tradição religiosa", ou seja, entende-se que a mulher, até meados do século XX, devia ser virtuosa e obediente às ordens postas, aquela que tentasse se desviar do tradicionalismo imposto seria mal vista.

Na Grécia antiga, ser mulher já indicava a posição que ocupava na sociedade "equivalente à do escravo no sentido de que tão somente estes executavam trabalhos 
manuais, extremamente desvalorizados pelo homem livre" (ALVES E PITANGUY, 1985, p.11), ou seja, ela era insignificante, sem função útil para a evolução humana. Os trabalhos femininos eram os domésticos, e as mulheres eram excluídas de um mundo intelectual "tão valorizado pela civilização grega" (p.11). Quando seus maridos iam para a guerra, e lá morriam, era obrigação da mulher grega escolher outro pretendente para representá-la, pois entendia-se que a mulher não tinha competência de cuidar sozinha de seu patrimônio.

Assim, precisavam lutar por direitos básicos, mínimos, que deveriam ser seus como cidadãs, sem precisar de lutas para isso, evidenciando, assim, as desigualdades entre os gêneros. Saffioti (1976) expõe que, na França, em 1789, Olympe de Gourges, defensora do feminismo propõe "a declaração dos direitos da mulher" (p.107), em que visava a abolição de privilégios masculinos, porém, a revolução, composta por homens burgueses, cala essa mulher e ameaça qualquer outra que entrasse em defesa da mesma proposta. Isso acarretou a consolidação de "uma ordem social na qual as mulheres continuariam marginalizadas da vida política, inferiorizadas, socialmente, em posição subalterna no grupo familiar e teriam de competir em desigualdades de condições com os homens pelas oportunidades econômicas" (SAFFIOTI, 1976, p.107). Entende-se que, devido à forte opressão nas sociedades patriarcais, as mulheres, até o século XVIII, não tinham muita força socialmente para reivindicar seus direitos: “O feminismo, todavia, não morre; silencia-se por quase três décadas para ressurgir aliado ao socialismo utópico, estimulado inicialmente pelas ideias de Saint-Simon, e depois, por Fourier e Cabet" (SAFFIOTI, 1976, p.107). As ideias utópicas surgidas em 1832 agitam o movimento, porém não apresentam soluções para as condições das mulheres, apenas dão força e as estimulam a continuarem a lutar por sua liberdade social e política.

O movimento feminino ganhou poder "através da imprensa feminina que, no século XIX, melhor exprimiu o feminismo das mulheres das classes médias, que apelam às mulheres e não aos homens para sua libertação" (MICHEL, 1982, p. 63). As mulheres acreditavam que os homens não as representavam socialmente, somente uma mulher poderia fazer isso. Por isso, as feministas apelavam para as mulheres que 
reivindicassem igualdade de direitos no trabalho, no casamento e na família. Perrot (2007, p.154) explica que "Em sentido muito amplo, "feminismo", "feministas" designam aqueles e aquelas que se pronunciam e lutam pela igualdade dos sexos." Zolin afirma que "o feminismo organizado só entrou no cenário político na segunda metade do século XIX" (2003a, p.164), reivindicando o sufrágio feminino.

As conquistas, de fato, só vieram no decorrer do século XX. Beauvoir foi uma das primeiras a impulsionar o movimento, com a publicação de $O$ segundo sexo em,1949, em que defendia que a natureza não limitava os papeis femininos, mas sim a própria sociedade, com costumes e leis sexistas. Esta obra impulsionou muitas mulheres a perceberem seu lugar de submissão e se engajaram em movimentos feministas. Estes realizaram enormes conquistas, como: a abertura ao mercado de trabalho (embora com leis desiguais), o direito de frequentar escolas e universidades, de se divorciar, etc. Mesmo que injustiçadas no trabalho, elas não podiam parar: "porque é pelo trabalho que a mulher conquista sua dignidade de ser humano" (BEAUVOIR, 1980a, p.149).

O sexismo no âmbito doméstico, porém, ainda continuou forte por décadas. A mulher ainda era considerada inferior pelo sistema patriarcal, e sua condição é determinada pela posição que ocupa na sociedade: "A maternidade, em particular, só é respeitada na mulher casada; a mãe solteira permanece um objeto de escândalo". (BEAUVOIR, 1980b, p.171), sua obrigação ainda é o casamento, e depois ser mãe. A sociedade valorizava e respeitava a mulher casada e mãe, a celibatária se tornava serva do pai, do irmão e até mesmo do cunhado. No casamento, a maternidade era o dever da mulher, que devia, ainda, viver em prol dos filhos, amá-los incondicionalmente.

Além das conquistas em diversos espaços sociais, também na escrita, os movimentos feministas tentaram lutar para que a mulher tivesse mais representatividade, tanto como escritora como quanto personagem. Assim, discute-se, a seguir, a evolução da crítica feminista. 


\section{A TRAJETÓRIA DO FEMINISMO NA LITERATURA DE AUTORIA FEMININA}

Durante séculos as mulheres foram impedidas de exercer papéis fora do âmbito doméstico e, quando tentavam, eram facilmente silenciadas por violências simbólicas que já tinham determinado qual era o seu lugar na sociedade. Até o século XVIII, as mulheres eram quase proibidas de escrever: "Quer a razão que as mulheres não metam jamais o nariz num livro, jamais a mão numa pena [...]. Para a mulher, a agulha e o fuso. Para o homem, a maça de Hércules [...] A leitura abre as portas perigosas do imaginário. Uma mulher culta não é uma mulher" (PERROT, 2007, p.93). Apenas os homens tinham este privilégio e, em certo momento, quando as mulheres começaram a escrever, utilizavam pseudônimos masculinos para não serem reprimidas. Por viverem desde o nascimento em um lar patriarcal e receber uma educação que as subjugavam, elas mesmas chegavam a acreditar que eram inferiores: "Convencidas de sua insignificância, estendendo à sua vida passada o sentimento de pudor que lhes havia sido inculcado, muitas mulheres, no ocaso de sua existência, destruíam - ou destroem - seus papéis- pessoa" (PERROT, 2007, p. 21).

A escrita de autoria feminina era uma realidade distante: “à primeira vista, é algo quase impossível, devido a predominância do patriarcalismo manifestado na exaltação do escritor e na marginalização da mulher" (BONNICl, 2007, p.76), sendo também um impedimento para a emancipação das mulheres na literatura. $O$ não acesso à educação, as experiências de vida e a renda também restringiam sua liberdade intelectual. Somente no final do século XIX as mulheres tiveram acesso mais amplo à educação, e depois de muito tempo entraram em universidades. A escrita literária, até o Modernismo, tinha participação efetiva de escritores homens e os valores patriarcais limitavam a escrita de mulheres. Assim, as obras literárias figuravam mulheres sob o olhar estereotipado masculino. Zolin (2003a, p.190) afirma que:

As (os) crítica (os) feministas mostram como é recorrente o fato de obras literárias canônicas representarem a mulher a partir de repetição de estereótipos culturais, como, por exemplo, o da mulher sedutora, perigosa e imoral, o da mulher como megera, o da mulher indefesa e incapaz, entre outros. 
Os textos masculinos retratavam as mulheres quase sempre como anjos, que eram aceitas e defendidas pela sociedade, ou megeras, bruxas e prostitutas, mulheres que fugiam do tradicionalismo, mal vistas. Nos estilos românticos, a estereotipação se voltava ao modelo considerado ideal, e via-se a personagem principal sob os signos da fragilidade, da pureza e bondade; a vilã era personificada como independente e dona de si, sendo punida no fim do enredo. Inicialmente, a maior parte de obras literárias escritas por mulheres também imitava esse padrão estereotipado de figuração feminina, já que incorporavam a dominação, como sugere Bordieu (2019), e repetiam essa dominação ao criar personagens femininas similares àquelas descritas por escritores homens.

Aos poucos, porém, conforme os movimentos feministas reivindicavam direitos e posições menos passivas para as mulheres, a literatura de autoria feminina começa a refletir isso nas personagens femininas. As escritoras começaram a reverter os estereótipos masculinos, uma vez que as personagens das autoras eram atuantes, possuíam voz, traçavam seu destino, reagindo aos conflitos impostos. As leitoras eram influenciadas, desejando ter aquela mesma postura que as mulheres fictícias possuíam, levando-as a refletirem sobre suas condições, por isso a figuração de personagens independentes era uma arma contra o patriarcado, pois a escrita masculina predominava na sociedade, reforçando um padrão socialmente imposto de "mulher ideal". Sobre as novas condições das personagens de escrita feminina, Woolf (2019, p.75), relata que esse também era um propósito, dar voz às mulheres por meio da escrita "pois os livros têm a tendência de influenciar uns aos outros" e a literatura se tornou uma arma feminina na busca por liberdade.

A mulher, aos poucos, foi saindo do silêncio ao qual era submetida e ocupando diversos papeis que antes era proibida de exercer, entre eles, o da produção literária. O principal objetivo delas era assumir a própria voz, a própria escrita, uma vez que estavam relegadas à margem da literatura de autoria masculina. Por isso, Woolf (2019) esclarece que a escrita artística precisava de liberdade e de condições materiais para se realizar. Em sua obra Um teto todo seu, deixa bem clara a importância da mulher ter uma renda financeira, pois só assim poderia escrever e falar da realidade para 
transmiti-la, sem pressões ou perturbações do meio, que sempre contribuíram para a subordinação das mulheres.

Assim, na segunda metade do século XX, nascem vozes literárias femininas que começam a teorizar sobre o papel de submissão imposto à mulher por séculos. Os estudos de Beauvoir em O segundo sexo, de 1949 e o ensaio de Kate Millett, Sexual Politics, de 1970, são exemplos dessa crítica literária feminista. Millett afirma que a crítica literária feminista tem origem na história da mulher, e acaba, também, promovendo essa história, na medida em que se utiliza dela para denunciar e desconstruir estruturas patriarcais mantidas ao longo do tempo, manifestadas pela história. Sozinha, a mulher "se põe a pensar, atua e cria do mesmo modo que os homens" (NYE, 1995, p.118), pois sua independência era a chave para a libertação e produção de escritos femininos, como foi o caso de Simone de Beauvoir:

Ela escapou, diz, por um feliz acaso, das limitações de ser mulher. Nunca se sentiu discriminada, sempre se considerou igual aos homens. Isso lhe permite ser imparcial, olhar objetivamente a condição das mulheres, sobretudo visto ser claro a partir da sua perspectiva liberada que tantos outros problemas são mais urgentes e importantes (NYE, 1995, p.108).

Beauvoir se igualava aos homens, sempre se sentiu livre como eles, atuante e criadora, sem opressão. No entanto, tinha uma ampla visão de como a maioria das mulheres eram inferiorizadas e injustiçadas, numa sociedade extremamente machista, que sempre colocava essas mulheres à margem. Por isso, se volta para as condições das mulheres na sociedade e suas diversas formas de assujeitamento. Beauvoir (1980b) acredita que quando a mulher deixar de ser um construto social, e começar a se conhecer e mostrar suas capacidades de criadora, ela será livre, pois a escolha deve ser da mulher ao invés de ser imposta.

Além de Beauvoir, antes dela, outras tantas e importantes autoras de diversos países colaboraram e lutaram para a libertação das mulheres, principalmente a libertação intelectual, como "as inglesas Jane Austen, as irmãs Brontë, George Eliot, Virginia Woolf, etc., e as francesas Colette, Marguerite Yourcenar, Nathalie Sarraute, Marguerite Duras, Françoise Sagan etc" (PERROT, 2007, p.99). Todas essas autoras 
contribuíram com seus romances para a conquista do espaço feminino na literatura. Elaine Showalter e Kate Millett foram duas autoras que ajudaram a sistematizar a crítica literária feminista, em obras que analisam o papel da mulher como leitora e como escritora. Bonnici (2007, p. 49) crê que "a finalidade da crítica literária e de leitura feminista é focalizar a constituição do estilo, da imagística e das características do patriarcalismo numa determinada obra". Muitas autoras, mesmo que tentando personificar as mulheres fictícias com características diversificadas com o intuito de desconstruir os estereótipos da escrita masculina, ainda assim, acabavam sendo influenciadas pelos estereótipos da literatura canônica; dessa maneira, a crítica feminista tenta desconstruir esta padronização imposta ao gênero feminino por meio da literatura canônica.

Os estudos de Showalter e Millett levam à classificação das obras literárias em fases do feminismo literário, contribuindo para a discussão e divulgação de textos que apresentam à sociedade uma nova visão sobre o comportamento humano e as mudanças voltadas para as questões do gênero feminino. Showalter, (2014, p.11), em A Literature of their Own, ao estudar a autoria feminina na Inglaterra, entre os séculos XIX e XX, classificou a escrita feminina em três fases distintas:

Feminine, Feminist and Female. These are obviously not rigid categories, distinctly separable in time, to which individual writers can be assigned with perfect assurance. The phases overlap; there are feminist elements in feminine writing, and vice versa. One might also find all three phases in the career of a single novelist. ${ }^{3}$

Showalter pondera que a Fase feminina acabava por imitar padrões de figuração feminina das obras masculinas dominantes; a fase feminista focava em certos protestos contra a imposição de padrões e ruptura em personagens desafiadoras, rebeldes, questionadoras; e a fase fêmea seria marcada pela autodescoberta feminina, do que é ser, essencialmente, mulher. Ressalta, porém, que

\footnotetext{
${ }^{3}$ Feminina, Feminista e Fêmea. Obviamente, essas não são categorias rígidas, distintamente separáveis no tempo, às quais escritoras individuais podem ser classificadas com perfeita segurança. As fases se sobrepõem; existem elementos feministas na escrita feminina e vice-versa. Pode-se também encontrar todas as três fases na carreira de uma única romancista. (tradução nossa).
} 
não há rigidez nessa classificação, já que obras podem figurar personagens nas três fases, por exemplo.

A fase feminina seria bem representada pelas obras produzidas entre 1840 e 1880 , por exemplo. Os textos pertencentes a essa fase acabam expondo não apenas as ideologias dominadoras da sociedade, mas também, a estética da tradição literária masculina: os romances ainda apresentam os estereótipos femininos, personificando mulheres frágeis, inseguras e dominadas pelos maridos, como se nota claramente no romance Orgulho e preconceito, (1813), de Jane Austen.

Com o surgimento dos movimentos feministas e suas diversas conquistas, as mulheres têm a chance de se representar e criar suas próprias personagens. Elas questionam a posição que ocupam na sociedade e seus papéis limitados, denunciando as ideologias patriarcais dominantes e defendendo seus direitos. Showalter denomina essa fase de feminista, e a define como "[...] a phase of protest against these standards and values, and advocacy of minority rights and values, including a demand for autonomy $^{\prime 4}$ (2014, p. 11). Virginia Woolf representa essa fase por escrever que a mulher só seria livre intelectualmente se tivesse uma renda financeira própria, além disso, criava romances protagonizando mulheres independentes e fortes. Essa fase pode ser identificada na personagem Conceição, do romance $O$ quinze (1930), de Rachel de Queiroz, em que ela quebra a tradição, pois não se casa como as moças de sua época, tendo consciência dos fatos de que Vicente não atenderia suas expectativas intelectuais, ela não idealiza sua felicidade em um homem.

A terceira e última fase identificada por Showalter (2014) é chamada de fêmea, que é a fase da autodescoberta, iniciada na década de 1920, indo até os dias atuais, mas "entering a new stage of self-awareness about 1960" ${ }^{5}$, segundo Showalter (2014, p. 11), o que reflete a escrita de Atwood, que parece transcender as três fases descritas por Showalter. Nessa fase, a mulher se auto estuda, procura se conhecer, conhecer seu corpo e seus desejos, expressando-se sem pudores e buscando uma identidade própria. Assim, é possível identificar essa fase em Mrs. Dalloway (1925),

\footnotetext{
${ }^{4}$ [...] uma fase de protesto contra esses padrões e valores e a defesa dos direitos e valores das minorias, incluindo uma demanda por autonomia (Tradução nossa).

${ }^{5}$ entrando em um novo estágio de auto consciência a partir de 1960. (tradução nossa).
} 
romance de Virginia Woolf, em que a personagem, em um dia, relembra toda a sua vida ao se deparar com pessoas e eventos do passado. Clarissa Dalloway, passa, então, a refletir sobre o momento presente; se autoanalisando, começa a questionar seus atos, imaginando como seria sua vida se tivesse tomado decisões diferentes.

Entendidas as fases da autoria feminina, e o modo como a escrita feminina avançou na figuração de personagens femininas, importa verificar como isso se reflete no romance aqui analisado, A odisseia de Penélope, de Margaret Atwood, de 2005, considerando a autora como uma escritora que reflete muito sobre o papel feminino na sociedade, figurando personagens femininas como protagonistas, mesmo em obras metafóricas, distópicas ou reescritas, como a obra a ser analisada nesta pesquisa.

\section{A ODISSEIA DE PENÉLOPE SOB O VIÉS FEMINISTA}

Margaret Atwood nasceu em 1939, em Ottawa, no Canadá, e começou sua carreira literária escrevendo poemas desde muito jovem. Ao longo da vida, tem escrito contos, poemas, romances, além de artigos críticos na área de literatura e áreas sociais como ecologia, preservação ambiental, etc. Para Leite (2010, p. 56), em suas obras de ficção que tratam de protagonistas femininas (a maioria), "[...] a autora discorre sobre as questões de gênero, a condição e o papel da mulher numa sociedade patriarcal, em busca de uma identidade nacional e pessoal, defende a dignidade das mulheres e denunciando as situações de injustiça, marcando, assim, o seu território [...]." Neste sentido, Atwood tem sido entendida como uma autora que desconstrói certos estereótipos ainda repetidos na literatura e, em A Odisseia de Penélope, segundo Renaux (2009, p. 164) faz isso "ao entregar a narrativa à Penélope e às doze escravas enforcadas, a fim de contestar e desconstruir parodicamente a autoridade da posição masculina e do sistema patriarcal vigentes." Renaux (2009, p. 164) foca sua análise no coro das escravas, que "reconstrói não apenas sua história, mas cria simultaneamente sua própria linguagem - polifônica, paródica, acusadora- desconstruindo assim também a imagem do herói homérico."

Sobre este romance, que se divide em 29 capítulos, sendo 18 de Penélope e 11 das escravas, Ribeiro e Silva, num artigo comparativo entre a Penélope de Atwood e 
Capitu, de Machado de Assis, acreditam que o romance tenha o intuito de "dar voz à personagem silenciada e mostrar um ponto de vista diferente daquele proposto por Homero, isto é, representar a posição ativa da personagem que está subentendida no texto homérico" (2014, p.122), e é o que esta pesquisa objetiva analisar, com mais profundidade, de modo a entender como, ao reescrever o mito de Penélope do ponto de vista feminino, Atwood critica a sociedade patriarcal do antigo mundo grego; como as personagens femininas ganham voz e desmistificam os fatos contados sobre elas naquela época, exemplificando a subordinação e objetificação das mulheres. Ao analisar a obra em contraste com a Odisseia, Lima (2013, p. 5) entende que "Em uma disputa metaficcional, as narradoras sobrepõem experiências e opiniões, buscando ter a última palavra (LIMA, 2013, p. 5)." No prólogo, a autora explicita o porquê da escrita da obra: "Sempre vivi assombrada pelas escravas enforcadas, ocorre o mesmo com Penélope" (ATWOOD, 2005, p. 13); por meio de Penélope, ela relata como uma injustiça o enforcamento das escravas, caso minimizado na Odisseia. Para recontar essa história, Atwood usa recursos literários como a metáfora, a ironia e a polifonia, que causam efeitos humorísticos na obra. Para Lima (2013, p. 53), A Odisseia de Penélope pode ser assim definida:

metaficcional, crítica, paródica, com protagonistas-narradoras "excêntricas", a trama de Atwood questiona a identidade e a condição feminina, trabalhando a relação conflituosa entre mulheres e sua posição na sociedade dominada por homens, além de retomar um tema mitológico e a imagem do submundo produtor de histórias.

Nessa versão, Penélope vivencia experiências diferentes do que Homero descreveu, pois a autora atribui a ela os conhecimentos do mundo moderno, no qual as mulheres já conquistaram a maior parte de seus direitos e um espaço em que podem ser ouvidas e expõem as injustiças que sofreram no passado, ou seja, a autora, como mulher que ganhou espaço na literatura, metaforiza este poder em Penélope, dando-Ihe voz também. Subvertendo tudo o que foi dito ao seu respeito, Penélope afirma: "agora que todos os outros perderam o fôlego, é a minha vez de fazer o relato" (ATWOOD, 2005, p.17), porque agora as mulheres têm voz tanto socialmente quanto na literatura, tendo assim mais liberdade de lutar por igualdades, elas possuem o teto 
todo seu reivindicado por Woolf (2019). Isso figura, metaforicamente, a evolução da própria escrita feminina, como analisou Showalter (2014), bem como a representação de personagens femininas que, de estereotipadas e submissas na fase feminina, passam a questionadoras e insubordinadas na fase feminista.

Na Odisseia, Penélope é submissa ao marido, uma esposa fiel, frágil, que chora quase todas as noites por sua ausência: "chorou por Odisseu, caro esposo" (ODISSEIA, canto I), sendo identificada como "a filha de Icário, Penélope bem-ajuizada" (ODISSEIA, canto I) e não apenas por seu nome, pois as mulheres eram as mulheres gregas eram socialmente representadas por homens: "Os homens são indivíduos, pessoas, trazem sobrenomes que são transmitidos" (PERROT, 2007, p.16), a mulher não era considerada um indivíduo, não tendo nem mesmo um sobrenome - apenas um nome e só eram reconhecidas pela posição que seu marido ou pai ocupava, sendo honradas por isso.

Atwood transforma essa mulher marginalizada em protagonista de sua história, possuidora de uma personalidade forte e revigorada, que não tem medo de desmascarar seu marido, e até o ridiculariza. Dessa forma, a obra é narrada por Penélope, subvertendo o foco da Odisseia, que era Odisseu, e jamais poderia ser Penélope na época, como entendeu Millett (1970) ao analisar que as obras de autoria masculina priorizavam protagonistas masculinos até meados do século XIX. A Penélope de Attwood reconta sua vida depois de três mil anos de reflexão, e se encontra amadurecida e detentora de uma percepção irônica. Já morta, observou a evolução da sociedade e a luta das mulheres pela independência e refletiu sobre sua vida, até o momento atual, simbolizando a própria maneira como a afiguração de personagens femininas evoluiu, na análise de Showalter (2014), chegando à ideia da fase fêmea, em que as personagens passam a se auto avaliar, o que ocorre com mais ênfase após os anos 1960 que fizeram eclodir os movimentos feministas no mundo, buscando o entendimento de si como mulheres, a construção de uma identidade própria, como faz Penélope após morrer.

Penélope adquiriu sabedoria para ter um olhar crítico sobre sua própria história e analisar uma injustiça cometida com suas escravas, que foram enforcadas 
sem que ousasse dizer a verdade, de que as escravas eram suas cúmplices e a ajudaram a enganar os pretendentes: "queria finais felizes naquela época, e os finais felizes são alcançados quando mantemos certas portas trancadas e dormimos na hora da confusão" (ATWOOD, 2005, p.16). Sendo uma esposa fiel e submissa, se Penélope tivesse tentado defender suas escravas, a teriam considerada suspeita, desfazendo seu final feliz, seu reencontro com Odisseu. Seu "final feliz", ironicamente, a faz se consumir de culpa e, modernamente, consegue entender que a felicidade era toda de Odisseu em ter uma esposa que o esperou por 20 anos e o recebeu de braços abertos, tendo sido fiel enquanto ele vivia aventuras, na clara figuração de personagens da fase feminina, ainda muito ligadas ao ideal de casamento como meio de felicidade, já que, como entende Beauvoir (1980a), a mulher era ensinada a ter o casamento como ideal de vida.

Por ter silenciado tantas vezes, ela demostra um certo arrependimento de ter se tornado um exemplo de fidelidade na Odisseia, relatando: "E o que me restou quando a versão oficial se consolidou? Ser uma lenda edificante. Um chicote para fustigar outras mulheres [...] não sigam meu exemplo, sinto vontade de gritar nos ouvidos de vocês - sim, nos de vocês! Mas, quando tento gritar pareço uma coruja" (ATWOOD, 2005, p.16). Afirma que suas atitudes condiziam com o mundo grego, mas não mais serviam para as mulheres modernas. A coruja simboliza a deusa Atena, que na Odisseia interpela as mulheres a servirem aos homens, representando uma mulher que concorda com o sistema patriarcal, aos moldes da incorporação da dominação, como entendida por Bordieu (2019, por meio de ideologias sexistas repassadas por discursos oficiais. Ao parecer uma coruja, esta Penélope "prudente" simboliza o silenciamento das mulheres por séculos.

$\mathrm{Na}$ narrativa de Homero, Penélope recai aos estereótipos dados à maternidade, em que as mães são cegas aos erros dos filhos, e assim ela o é com Telêmaco, quando ele ajuda no enforcamento das escravas. Porém, nessa nova narrativa, ela demonstra que percebe a crueldade do filho e queria seu afastamento "no momento, preferia que ocorresse outra guerra de Tróia para eu poder despachálo e me livrar dele" (ATWOOD, 2005, p. 136). Embora os estereótipos maternos 
focassem na dedicação cega das mães, esta figuração moderna de Penélope evidencia que, embora o ame, esta mãe é racional. Telêmaco é criado pelas empregadas da casa, e cresce interpelado pelas ideologias machistas, como entende Bordieu (2019), que predominavam na sociedade da época. Generalizando as mulheres, ele fala que: "como sempre eram excessivamente emotivas e não mostravam capacidade de julgamento e raciocínio" (ATWOOD, 2005, p.108), reproduzindo pensamentos sexistas sobre a inferioridade feminina. Quer buscar o pai, pois acredita que a mãe seja fraca para defender o reino: "se Ihes restasse alguma herança não seria graças a ela, pois esta não soube defendê-la [...]" (ATWOOD, 2005, p.108). Telêmaco não questiona a demora no retorno do pai, que aproveitava a desculpa da guerra para viver aventuras sexuais ao longo dos anos, mas coloca em xeque a suposta fraqueza da mãe o tempo todo, numa clara reprodução dos papeis sociais atribuídos a homens e mulheres neste mundo grego: a mãe é fraca e desprezível, o pai forte e admirado.

Outro fato que Atwood subverte é a condição das escravas, que de menosprezadas passam a ter voz, tendo a liberdade de falar, julgar e reavaliar todos os atos aos quais foram submetidas no passado. Agora que são espíritos, elas buscam vingança contra seus assassinos e, juntas, formam um coro cheio de sarcasmo que denuncia sua antiga condição de objeto. Homero, na Odisseia, não se preocupa em identificar quem foram as 12 escravas mortas, mas sendo Penélope a narradora desta história, se preocupa em humanizar essas escravas, lhes dando nomes e características próprias. As escravas ganham o direito de recontar suas histórias de vida desde a infância, intercaladas com as de Penélope, desconstruindo e condenando o herói épico. A história tem somente mulheres como protagonistas e narradoras, numa demonstração de como a autoria feminina do século XXI consegue inverter o papeis de protagonismo masculino mais comuns nas literaturas de autoria masculina, principalmente até meados do século XIX, como crê Showalter (2014).

Penélope desmascara a idealização de seu marido como herói, visto na Odisseia como inteligente e corajoso. Ironicamente, analisa que os "obstáculos" ao retorno de Odisseu, após a guerra de Troia, incluíam o sexo com lindas mulheres e deusas, seduzidas por ele. Sobre os feitos de Odisseu, relata que "com certeza, os 
menestréis enfatizavam, por adulação" (ATWOOD, 2005, p.76), e que certamente eram apenas aventuras de um homem que não tinha pressa em voltar para casa. Dessa forma, Penélope desconstrói tudo o que foi dito sobre Odisseu e sua viagem, mostrando que ela sempre soube a verdade e que não era tão submissa como conta a história de Homero, embora em muitos momentos assim o agisse, para que a fama de seu marido continuasse a crescer, atitude esperada das mulheres gregas de então. A inteligência das mulheres em nenhum momento podia se sobressair a do homem, porque a sociedade não permitia que as regras do patriarcado fossem invertidas, como afirma Perrot (2007), ao analisar como a inteligência era tida como característica apenas masculina, por isso Penélope oculta a verdade e concorda com a posição à qual é relegada.

Homero relata que Odisseu disfarçou-se de mendigo quando retornou para Ítaca para que os pretendentes não lhe preparassem uma armadilha e também para ter certeza sobre a fidelidade da esposa, e Penélope não o reconhece. Penélope conta o episódio de outra forma, teria fingido não saber de nada, mas assim que Odisseu entrou no palácio, ela logo desconfiou daquelas pernas curtas: "assim que vi o peito amplo e as pernas curtas comecei a suspeitar" (ATWOOD, 2005, p.113). Ao se referir às pernas de Odisseu, Penélope, ironicamente, desmitifica a ideia de que Odisseu era belo e irresistível, pois ele conquistava outras mulheres com suas histórias engraçadas e não por sua aparência. Quando a ama Euricléia lava os pés deste Odisseu disfarçado e o reconhece, a Odisseia relata que ela tenta avisar Penélope, que não percebe. Na nova versão, Penélope nos esclarece que já o havia reconhecido, e que "Quem acreditar nisso acredita em qualquer absurdo. Na verdade, dei as costas aos dois para disfarçar meu riso silencioso, provocado pelo êxito de meu estratagema" (ATWOOD, 2005, p.116). Deste modo, Penélope sabia que Odisseu testaria sua fidelidade. Ela apenas colaborou com o marido, para não diminui-lo diante dos outros. Enquanto Odisseu é considerado herói por histórias que não foram comprovadas, ela é considerada a mulher que foi fiel ao herói, demonstrando, mais uma vez, sua subalternidade. Mas, assim como Odisseu constrói o cavalo de Tróia, Penélope tece de 
dia e desfaz à noite um manto, enganando os pretendentes por três anos, mostrando que os dois são iguais e têm sagacidades semelhantes.

Analisando os episódios com as escravas, que foram acusadas de traição por terem relações sexuais com os pretendentes sem a permissão de seu dono, Penélope afirma que seus enforcamentos foram uma injustiça, já que Odisseu não procurou saber a verdade, nem perguntou sua opinião, apenas pediu que sua ama indicasse as traidoras. Euricléia tinha a mesma visão que um homem tinha sobre a mulher, pois ela internalizou as ordens do patriarcado, aceitando a submissão, reforçando a incorporação da dominação descrita por Bordieu (2019), e condenando as mulheres que pensavam diferente, por isso não hesita em denunciar as escravas. Os construtos sociais estavam fixados em suas ideias, em que a mulher era inferior e tinha que seguir as ordens do patriarcado, reforçando a sua existência, pois ela era interpelada por esse discurso, o aceitando como único e verdadeiro, e repetindo isso. Sendo assim, condenava aquelas que fugissem às normas impostas ao feminino, simbolizando muitas personagens da fase feminina, ainda inconscientes de que seu papel de submissão era apenas um construto patriarcal.

Nesta nova obra, as escravas cantam num coro de forma bastante satírica, e com um uso predominante de metáforas, revelando como eram vistas como objetos sexuais aos seus donos, enquanto eram novas serviam para o trabalho doméstico e para a relação sexual, na velhice eram exploradas nas tarefas domésticas, tendo que trabalhar para os donos até sua morte. Assim se descrevem:

Diziam que éramos sujas. Nós éramos sujas. A sujeira era nossa preocupação, nossa responsabilidade, nossa especialidade, nossa culpa. Se nossos donos, seus filhos, um nobre visitante ou os filhos dele quisessem deitar conosco, não poderíamos recusar. Não adiantava chorar, não adiantava dizer que doía. Isso tudo aconteceu conosco quando éramos crianças" (ATWOOD, 2005, p.24).

A ideia da sujeira revela a dupla subalternização destas mulheres, que também eram escravas. Mostra, também, a contradição do discurso patriarcal, pois mesmo sujas serviam para o sexo. O sexo, porém, era forçado, sendo o estupro algo constante na vida das escravas. Porém, nessa nova versão, essas escravas também possuem os 
conhecimentos do mundo moderno e sabem dos seus direitos, e levam Odisseu para um tribunal do século XXI, no qual prevalecem as leis desse século que garantem o direito de as mulheres serem ouvidas. Porém, logo percebem que as leis são falhas, pois o juiz se recusa a resolver um caso de três mil anos antes. Odisseu levou 20 anos para construir uma imagem de herói e o juiz, homem, se recusa a denegrir esta imagem, de modo que as regras machistas se evidenciem como ainda vigentes, e a representação destas mulheres, em termos legais, jamais conseguiria ser justa enquanto não houvessem mulheres como legisladoras, numa clara crítica à falta de representatividade feminina no campo judiciário. As escravas, como personagens, são questionadoras e sabem da injustiça cometida, sendo personagens muito semelhantes àquelas da fase feminista.

É notável que as escravas não eram tratadas como seres humanos e não tinham importância para a sociedade, no coro elas expõem que nasceram juntas com o filho de Penélope, porém o nascimento dele foi festejado e os delas não: "sua mãe ofertou um príncipe. Nossas diversas mães desovaram apenas, pariram, puseram ovo, expeliram, partejaram, desembucharam, descansaram e despejaram, produziram sua ninhada" (ATWOOD, 2005, p.63). Esses verbos são usados para mostrar a animalização de suas mães, que não eram nada, não tinham papel algum na sociedade, pois só colocavam mais objetos no mundo.

Enquanto na Odisséia são vistas como oferecidas e impertinentes, tendo traído seu dono, a nova Penélope as trata como amigas, pois confia nelas, já que estavam com ela desde o nascimento. Elas importam como seres humanos, não são meros objetos, ao contrário elas defendem e ajudam Penélope, havendo cumplicidade entre as mulheres que se ajudam a sobreviver no patriarcado, reforçando a ideia da necessidade da sororidade para o empoderamento feminino. Refletindo sobre as mortes das escravas, Penélope diz que: "A culpa foi minha” (ATWOOD, 2005, p.129), pois em nenhum momento ela se impôs para salvá-las e nem revelou como elas ajudaram sendo prestativas e amigas que guardavam confissões.

Penélope, ao ficar em silêncio, deixou que outras versões ao seu respeito surgissem, como a de símbolo da moralidade, mas se defende: "o que uma mulher 
pode fazer quando mexericos escandalosos percorrem o mundo? Se ela se defende, soa culpada. Por isso esperei mais um pouco" (ATWOOD, 2005, p.17), e agora, ao fazer seu relato, ela descobre que poderia ter mudado o destino das escravas contando como elas eram fiéis a ela. Porém, naquela época, existiam discursos maiores que o seu, que a dominavam, por isso ela esperou: "a essa altura não me importo mais com a opinião pública" (ATWOOD, 2005, p.17). Ela denomina sua história como uma arte muito importante, já que vem denunciando as atitudes de seu marido e contestando o lugar de autoridade em que Homero posiciona o homem, analisando-se, entendendose como mulher, não mais esposa de Odisseu, não mais a filha de Icário, mas um ser com identidade própria, uma típica personagem da fase fêmea. Evidencia-se que a reescrita de Atwood serve como uma metáfora do lugar da mulher no mundo e da própria figuração de personagens femininas na literatura, que de passiva e calada, como foi Penélope, passou a questionar, lutar por direitos e a refletir sobre o seu lugar no mundo e a construir uma identidade.

\section{CONSIDERAÇÕES FINAIS}

Margaret Atwood desconstrói a personagem criada por Homero, que por ser um escritor homem colocava em suas personagens o reflexo de como as mulheres eram vistas naquela época, na Grécia Antiga, subordinadas aos homens, tidas como inferiores e desprovidas de inteligência. O homem era designado por sua força, intelectualidade, autoridade e racionalidade, à mulher cabia somente a obediência e a procriação. Essa imagem de fragilidade física e psicológica das mulheres permitiu que elas mesmas acreditassem que suas naturezas eram inferiores aos homens, sendo construído o que era ser socialmente homem e o que era ser mulher, para que fossem reforçados os conceitos de dominação e fragilidade.

Uma forma encontrada pelas mulheres para desconstruir alguns rótulos que Ihes eram imputados foi através da literatura, pois a escrita produzida sobre mulheres e por mulheres ajudava a desconstruir alguns estereótipos reducionistas, ao mostrar mulheres insubordinadas e ativas que tinham voz, encorajando as mulheres em suas lutas e combate ao machismo. Desta maneira, o movimento literário feminista foi 
evoluindo e se modificando conforme a mulher assumia novos papéis, adquirindo gradualmente um lugar na sociedade e na literatura, que era até então dominada pela escrita masculina. Com a busca por igualdade, as mulheres reivindicaram seus direitos como cidadãs. A crítica feminista vem discutir os estereótipos colocados sobre a mulher desde a Grécia antiga, em que esta deveria ser frágil, dócil e indefesa. Com a desconstrução desses rótulos, a mulher assumiu novos papéis, sendo forte igualmente aos homens, ativa e dona de suas vontades. Muitas obras, no decorrer dos séculos, vieram mostrar sua evolução, dessa mesma forma acontece com o romance aqui analisado, em que a autora faz da personagem a protagonista de sua história, sendo questionadora, irônica e insubordinada.

Dessa maneira, Penélope revela que as escravas, tidas como culpadas na Odisseia, eram amigas e apoiadoras, e Ihes devolve a humanidade, dá-Ihes a posição de sujeito, que não tinham na Grécia antiga. Portanto, Penélope também vem denunciar a posição dessas personagens femininas dada por Homero: sujas, mentirosas, dignas do enforcamento, quando, em verdade, foram desumanizadas, violadas e mortas injustamente.

Comparando a Penélope de Homero com a de Atwood é possível notar que houve uma evolução da mulher tanto na sociedade, quanto na escrita literária. A escrita de Homero representava o pensamento da época, em que até na escrita literária as ações das personagens femininas eram limitadas, por causa da subalternidade das mulheres no meio social. Isso é evidenciado quando Homero trata um caso de grande importância, como foi a morte das escravas, como um ato irrelevante. E Atwood reformula não só a história de Penélope, mas das escravas também, dando-Ihes voz e consciência de si, de modo a evidenciar como a figuração das personagens femininas mudou.

\section{REFERÊNCIAS BIBLIOGRÁFICAS}

ALVES, Branca Moreira. PITANGUY, Jacqueline. O que é Feminismo. São Paulo: Abril, 1985.

ATWOOD, Margaret. A odisseia de Penélope. Trad. Celso Nogueira. São Paulo: Companhia das Letras, 2005. 
BEAUVOIR, Simone de. O Segundo sexo: Fatos e mitos. Tradução de Sérgio Milliet. Rio de Janeiro: Nova Fronteira, 1980a.

BEAUVOIR, Simone de. O Segundo sexo: a experiência vivida Tradução de Sérgio Milliet. Rio de Janeiro: Nova Fronteira, 1980b.

BONNICl, Thomas. Teoria e Crítica literária feminista: conceitos e tendências. Maringá: Eduem, 2007.

BORDIEU, Pierre. A Dominação Masculina: A Condição Feminina e a Violência Simbólica. Rio de Janeiro: Bertrand Brasil, 2019.

HOMERO. Odisséia. Trad. Christian Werner. São Paulo: Cosac Nayf, 2014.

LEITE, Maria do Rosário Silva. The Penelopiad: a reconstrução do mito por Margaret Atwood. 132 p. Dissertação. (Mestrado em literatura). João Pessoa, UFPB, 2010.

LIMA, Kelly. Penelopeia: Figurações de Penélope na Odisseia, de Homero, e em A odisseia de Penélope, de Margaret Atwood. 115 p. Dissertação. (Mestrado em Letras). Curitiba, UFPR, 2013.

MICHEL, André. O Feminismo: Uma abordagem histórica. Rio de Janeiro: Zahar, 1982.

MILLETT, Kate. Política Sexual. Trad. Alice Sampaio, Gisela da Conceição e Manuela Torres. Lisboa: Publicações Dom Quixote, 1970.

NYE, Andrea. Teoria Feminista e as filosofias do homem. Trad. Nathanael C. Caixeiro. Rio de janeiro: Record/Rosa dos Tempos, 1995.

PERROT, Michele. Minha história das mulheres. Trad. Angela M. S. Corrêa. São Paulo: Contexto, 2007.

RENAUX, Sigrid P. M. L. S. Da Odisséia à Odisséia de Penélope: O coro de escravas como porta-voz da alteridade, violência e redenção. Revista Letras, Curitiba, n. 77, p. 139-166, Jan/Abr. 2009. Editora UFPR.

RIBEIRO, Anailde da Silva; SILVA, Avanilda Torres da. A construção do ardil feminino na literatura: sob a perspectiva de Penélope e Capitolina. Revista Letras Raras. Vol. 3, №1 - 2014. P. 122-143.

SAFFIOTI, Heleieth I. B. A mulher na sociedade de classes: Mito e realidade. Petrópolis: Vozes, 1976.

SHOWALTER, Elaine. A literature of Their Own. London: Virago Press, 2014. 
WOOLF, Virginia. Um teto todo seu. Trad. Vera Ribeiro; prefácio Ana Maria Machado. 2 ed. Rio de Janeiro: Nova Fronteira, 2019.

ZOLIN, Lúcia Osana. Crítica Feminista In: BONNICl, Thomas; ZOLIN, Lúcia Osana. Teoria Literária: Abordagens históricas e tendências contemporâneas. Maringá: Eduem, 2003a, p. 161-183.

ZOLIN, Lúcia Osana. Literatura de autoria feminina. In: BONNICl, Thomas; ZOLIN, Lúcia Osana. Teoria Literária: Abordagens históricas e tendências contemporâneas. Maringá: Eduem, 2003b, p-253-261.

Recebido em 15 de Abril de 2020.

Aprovado em 10 de maio de 2020 